\title{
A case of distal renal tubular acidosis, Southeast Asian ovalocytosis and possible fluorosis
}

\author{
J P Vithanage ${ }^{1}$ and $M$ Ekanayake ${ }^{1}$ \\ (Index words: distal renal tubular acidosis, Southeast Asian ovalocytosis, fluorosis)
}

\begin{abstract}
A 39-year old man had periodic paralysis due to hypokalaemia. Investigations led to the diagnosis of distal renal tubular acidosis (dRTA) and Southeast Asian ovalocytosis (SAO). Both can originate in mutations of the anion-exchanger 1 gene (AE1), which codes for band 3 , the bicarbonate/chloride exchanger in both the red cell membrane and the basolateral membrane of the collecting tubule alpha-intercalated cell. The finding of diffuse osteosclerosis led to the suspicion of coexisting fluorosis.
\end{abstract}

\section{Case report}

A 39-year old man developed quadriparesis. He had been diagnosed with hypokalaemic periodic paralysis at the age of 23 years, and was on self medication with potassium chloride tablets. He had weight loss, polyuria and polydipsia. His father died of an undiagnosed renal disease. There was no renal disease or periodic paralysis amongst his four siblings. Neurological examination revealed hypotonia and grade $4 / 5$ weakness of upper limbs and grade $3 / 5$ weakness of lower limbs with normal reflexes. The remainder of the neurological examination was unremarkable and other systems were normal except for yellowish enamel discolouration.

Serum sodium and potassium concentrations were $142 \mathrm{mmol} / \mathrm{L}$ and $1.78 \mathrm{mmol} / \mathrm{L}$ respectively. Neurological examination was normal following the correction of hypokalaemia. Arterial blood gas (ABG) analysis revealed a metabolic acidosis with a $\mathrm{pH}$ of $7.27, \mathrm{pCO}_{2}$ of $30.8 \mathrm{mmHg}$, $\mathrm{pO}_{2}$ of $106.7 \mathrm{mmHg}, \mathrm{HCO}_{3}$ of $15.8 \mathrm{mmol} / \mathrm{L}$ and a base deficit of $11.3 \mathrm{mmol} / \mathrm{L}$. Despite the acidosis, the urine $\mathrm{pH}$ was 7 , raising the possibility of distal (type1) renal tubular acidosis. Serum chloride concentration was $99 \mathrm{mmol} / \mathrm{L}$. The anion gap $\left\{\left[\mathrm{Na}^{+}\right]-\left[\mathrm{Cl}^{-}\right]-\left[\mathrm{HCO}_{3}^{-}\right]\right.$or $\left[\mathrm{Na}^{+}\right]+\left[\mathrm{K}^{+}\right]-\left[\mathrm{Cl}^{-}\right]-$ $\left.\left[\mathrm{HCO}_{3}^{-}\right]\right\}$was high (23-25). Urine potassium concentration was high $(22.3 \mathrm{mmol} / \mathrm{L})$ despite hypokalaemia. Urinalysis was normal. Serum creatinine was elevated $(155 \mu \mathrm{mol} / \mathrm{L})$ with a normal serum urea concentration. The 24 hour urine volume was $3740 \mathrm{ml}$ with a creatinine clearance of $34.4 \mathrm{ml} /$ min. Ultrasound scan of the abdomen revealed nephrocalcinosis with no evidence of chronic parenchymal renal disease. 24 hour urinary calcium excretion was normal.
Serum calcium and phosphate were both low $(2.04 \mathrm{mmol} /$ $\mathrm{L}$ and $0.66 \mathrm{mmol} / \mathrm{L}$ respectively) with a raised serum alkaline phosphatase (654 U/L) suggestive of osteomalacia. Hormonal assays showed normal thyroid and intact parathyroid hormone levels. Fasting blood sugar, serum proteins, liver transaminase levels were normal. He was negative for antinuclear antibody (ANA). The full blood count was normal except for a raised MCV (108 fL) and $\mathrm{MCH}(36 \mathrm{pg}$ ). The blood picture showed stomatocytic macro-ovalocytes compatible with Southeast Asian ovalocytosis.

There was radiological evidence of nephrocalcinosis and diffuse osteosclerosis without any significant ligamental calcification. Prostate specific antigen level was normal. The authors believe that this diffuse osteosclerosis is due to fluorosis, as the patient originally came from Anuradhapura, an area known to have high fluoride content in water. Exposure to fluoride was also evident by the enamel appearance. He was treated with potassium chloride tablets and sodium bicarbonate solution with the dose titrated according to serum potassium and $A B G$ values respectively. Oral calcium supplementation was also given. The patient had no symptoms related to fluorosis and no specific treatment was given.

\section{Discussion}

Renal tubular acidosis is a disorder of renal acidification out of proportion to the reduction in glomerular filtration rate. In type 1 or distal renal tubular acidosis (dRTA), the distal nephron is unable to lower the urine $\mathrm{pH}$ normally. It consists of a syndrome of hypokalaemia, hyperchloraemic metabolic acidosis with normal anion gap, inability to lower urine $\mathrm{pH}$ below 5.5, nephrocalcinosis and osteomalacia or renal rickets. Hypercalciuria is found in some patients with dRTA [1]. Several tubular defects give rise to dRTA, including defective $\mathrm{H}^{+}$-ATPase, $\mathrm{H}^{+} / \mathrm{K}^{+}$-ATPase and abnormal anion exchange [2].

The absence of hyperchloraemia and normal anion gap in this patient may have been due to the coexisting renal impairment or an error in the measurement of serum

${ }^{1}$ General Medical Unit (Ward 45), National Hospital of Sri Lanka, Colombo.

Correspondence: TPV, e-mail: <cjvithanage@yahoo.com>. Received 24 March and revised version accepted 7 December 2008. Competing interests: none declared. 
chloride [3]. Ammonium chloride loading test was not indicated in our patient due to the apparent acidosis [4]. The fasting urine $\mathrm{pH}$ was above 6.1 and favoured the diagnosis of renal tubular acidosis [5].

Southeast Asian ovalocytosis (SAO), as its name implies, found almost exclusively in Southeast Asia [6]. It is usually asymptomatic and results from a mutation of the anion exchanger 1 gene (AE1), which results in a 9amino-acid deletion of band 3, the most abundant of the red cell membrane proteins [6]. Band 3 is both a structural component and the chloride-bicarbonate anion exchanger in the red cell membrane. The heterozygous presence of the SAO mutation is sufficient to produce the ovalocyte morphology [7].

A form of band 3 is present on the basolateral membrane of the $\alpha$-intercalated cells of the renal collecting duct and is involved in renal tubular acid secretion [7]. Different mutations of the band 3 gene (AE1) which give rise to dRTA have been described [8]. SAO mutation alone does not result in dRTA [7]. The combination of SAO and dRTA occurs in individuals who are compound heterozygotes to both the dRTA and the SAO mutations of band 3 gene.

Fluorosis and renal osteodystrophy were the likely possibilities for the osteosclerosis in this patient [8]. Secondary hyperparathyroidism and the almost diagnostic 'rugger jersey spine' of osteosclerosis associated with renal osteodystrophy were absent in our patient. Diagnostic facilities were unavailable to confirm fluorosis, which was probably an incidental finding in this patient.

Osteomalacia in dRTA is well documented [9]. Our patient had biochemical evidence of osteomalacia. However, radiological appearance and iliac crest biopsy did not support the diagnosis. Fluorosis may give rise to biochemical and histological evidence of osteomalacia, in the presence of a radiological appearance of diffuse sclerosis [8].

SAO has been reported in Sri Lanka [10]. To our knowledge, this is the first reported case of SAO and dRTA in Sri Lanka.

\section{Acknowledgements}

We thank Dr. S. V. Alahakoon (Consultant Radiologist), Dr. Mala Tudawe (Consultant Haematologist) and Dr. Ruchira Fernando (Consultant Histopathologist) of National Hospital of Sri Lanka for their help in the investigation of our patient.

\section{References}

1. Buckalew VM. Nephrolithiasis in renal tubular acidosis. The Journal of Urology 1989; 141: 731-7.

2. Kurtzman NA. Renal tubular acidosis syndromes. Southern Medical Journal 2000; 93: 1042-52.

3. Kraut JA, Madias NE. Serum anion gap: its uses and limitations in clinical medicine. Clinical Journal of the American Society of Nephrology 2007; 2: 162-74.

4. Penney MD, Oleesky DA. Renal tubular acidosis. Annals of Clinical Biochemistry 1999; 36: 408-22.

5. Chafe L, Gault MH. First morning urine $\mathrm{pH}$ in the diagnosis of renal tubular acidosis with nephrolithiasis. Clinical Nephrology 1994; 41: 159-62.

6. Wrong O, Bruce LJ, Unwin RJ, Toye AM, Tanner MJA. Band 3 mutations, distal renal tubular acidosis, and southeast Asian ovalocytosis. Kidney International 2002; 62:10-9.

7. Bruce LJ, Wrong O, Toye AM, Young MT, Ogle G, et al. Band 3 mutations, renal tubular acidosis and southeast Asian ovalocytosis in Malaysia and Papua New Guinea: loss of up to $95 \%$ band 3 transport in red cells. The Biochemical Journal 2000; 350: 41-51.

8. Kiely PDW, Chow J, Eastwood JB, Bourke BE. Fluorosis and osteomalacia. Arthritis and Rheumatism 1999; 42: 2012-13.

9. Nilwarangkur S, Nimmannit S, Chaovakul V, Susaengrat W, Ong-aj-Yooth S, et al. Endemic primary distal renal tubular acidosis in Thailand. The Quarterly Journal of Medicine 1990; 74: 289-301.

10. Vidyatilake HMS, Gooneratne LV. Two families in Sri Lanka with southeast Asian ovalocytosis. Ceylon Medical Journal 2004; 49: 27-9. 